\title{
NESTING BEHAVIOR AND DESCRIPTION OF THE LARVA OF BOTHYNOSTETHUS DISTINCTUS FOX
} (HYMENOPTERA: SPHECIDAE)

\author{
By Frank E. Kurczewski ${ }^{1}$ and Howard E. Evans ${ }^{2}$
}

Bothynostethus is a predominantly neotropical genus having a single described species, distinctus Fox, in America north of Mexico. The genus has been little studied, and its placement in the sphecid classification has been the subject of some dispute. Kohl (I896) and Handlirsch (1925) put Bothynostethus in the Nyssoninae and related it to Alysson. In the Synoptic Catalog of Hymenoptera of America North of Mexico, Krombein (195I) placed it in the tribe Miscophini of the subfamily Larrinae. More recently, Menke (1968) grouped Bothynostethus, Scapheutes, Willinkiella, and Bohartella in the tribe Bothynostethini of the subfamily Larrinae. However, Evans (1964) has questioned, on the basis of larval structure, whether the Larrinae and Crabroninae deserve the status of separate subfamilies, and he has cited Bothynostethus as a genus in which the adults resemble certain Crabroninae. Despite Menke's (1968) inclusion of the Bothynostethini in the Larrinae, he informs us (correspondence) that Bothynostethus is not a "typical" member of the subfamily, and that "it would not be difficult to derive a crabronid from a Bothynostethus-like ancestor".

It is clearly of interest to discover what light a study of nesting behavior and larval structure may shed on these problems. Cazier and Mortenson (1965) found $B$. distinctus nesting in the ground and preying upon a chrysomelid beetle, but otherwise the genus has not been studied in the field. Recently we discovered a small aggregation of $B$. distinctus nesting near Albany, N. Y., and a single individual nesting in Bedford, Mass., and we are able to present considerable new information on nesting behavior as well as a description of the mature larva. Our studies represent the first records of the species from those two states, as it has not previously been reported from north of New Jersey. In the Discussion we reconsider the proper phylogenetic placement of Bothynostethus. The specimens from our studies bear our note numbers and have

\footnotetext{
${ }^{1}$ Department of Forest Entomology, State University College of Forestry, Syracuse, New York 13210.

${ }^{2}$ Museum of Comparative Zoology, Harvard University, Cambridge, Massachusetts 02138 .

Manuscript received by the editor July 5, 1972.
} 

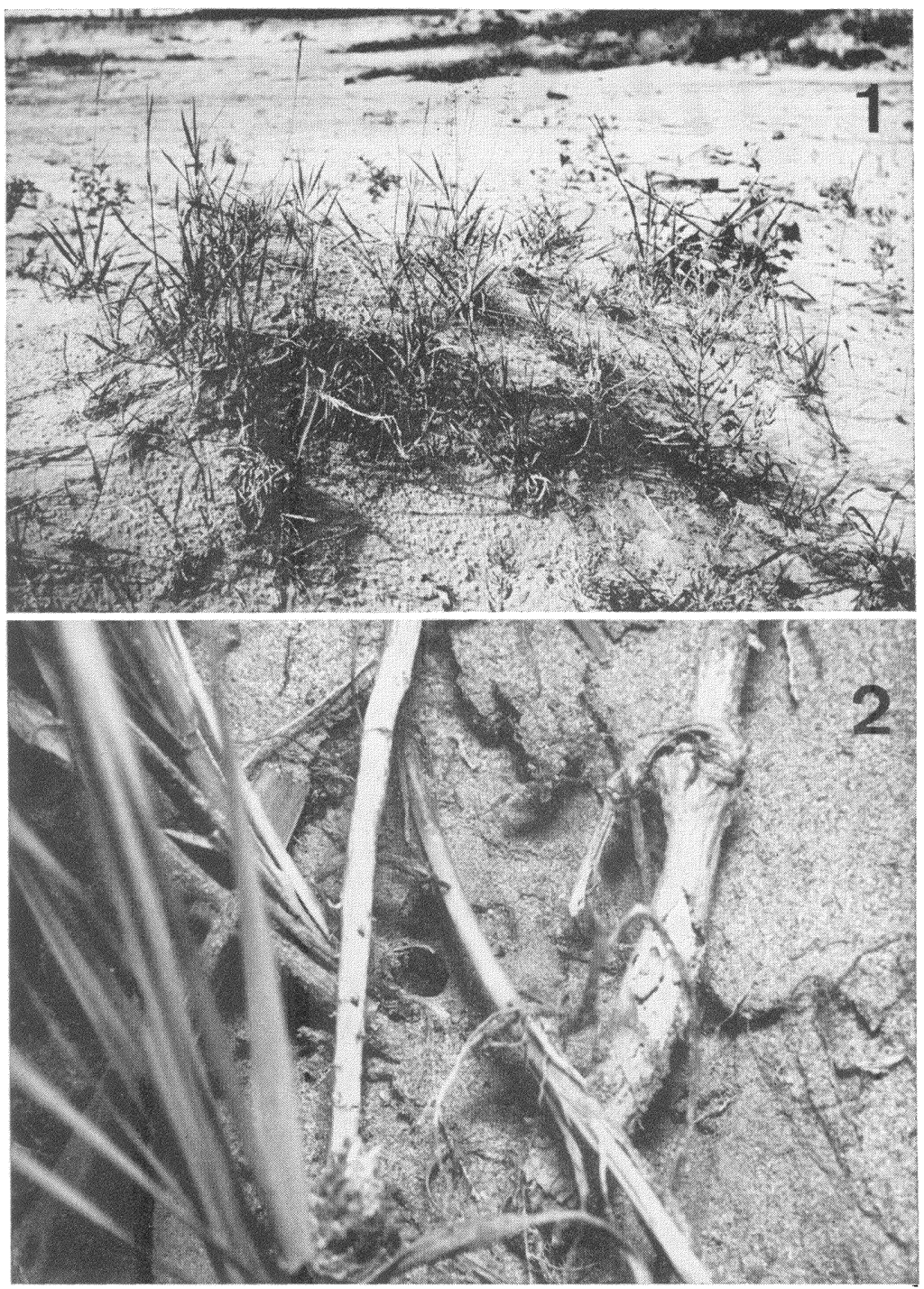

Fig. 1. Nesting-site of Bothynostethus distinctus - a mound of sand in a sandpit near Colonie, Albany Co., N. Y.

Fig. 2. Entrance (center) to nest of Bothynostethus distinctus. Note surrounding rootlets and grass blades. 
been deposited in the Museum of Comparative Zoology, Cambridge, Mass., and the SUNY College of Forestry, Syracuse, N. Y.

\section{Nesting Behavior}

Ecology. Our observations on $B$. distinctus were made at two widely-separated localities. The first site, a small mound of sand overgrown with sparse grasses and other plants (Fig. I), occupied a portion of a man-made sand pit near Colonie, Albany County, New York. The entrances to three nests were located in the vertical sides of the mound, just beneath the overhang (Fig. 2), and were situated so that they did not receive direct rainfall or sunlight. A fourth female was captured on a sand cliff several meters away but her nest was not discovered. The second area, in Bedford, Middlesex County, Massachusetts, comprised a sand-bank with a slope of about $45^{\circ}$. One nest entrance was located in the side of the bank, near a projecting stone. At both sites the entrances were left open by the wasps during the periods of observation, although the burrows could have been closed farther inside.

At Colonie we observed females provisioning nests between July 7 and I6, I970, whereas at Bedford one of us ( $\mathrm{HEE}$ ) noted a female nesting on Sept. 22, I97I. These collective dates of observation suggest that $B$. distinctus may have two generations per year in the Northeast, although the possibility of a single generation with staggered emergence should not be overlooked.

Cazier and Mortenson (1965) found $B$. distinctus nesting in "bare ... sandy soil" near Portal, Arizona. One nest was located inside a vertical rodent burrow, the entrance being situated $5 \mathrm{~cm}$ below ground level on the "east wall."

Burrow construction. $B$. distinctus females apparently do not begin their burrows from the sand surface but utilize appropriatesized nests of other insects, possibly those of solitary wasps, bees, or tiger-beetles. These burrows are renovated and modified accordingly. One wasp at Colonie was observed searching for a nest-site along the vertical portion of the sand mound underneath the overhang. She flew slowly and non-randomly, entering a variety of open burrows of small diameter. She would often exit several seconds after entering and resume her searching. In flight, her behavior resembled that of a Mimesa or small Trypoxylon, both of which search for pre-existing burrows in a similar manner. After repeatedly entering and leaving a burrow of small diameter behind a spider web, she stayed inside for several minutes. She was later dug out of this 
burrow and collected, facing head outward, $6 \mathrm{~cm}$ from the entrance. The "weak tarsal rake" of the foreleg of the female (Menke, I968) and the variation in the burrow configurations and the positions of the cells suggest that females of this species use pre-existing burrows for the initial portions of their nests.

Prey transport, entry, and exit. Two females (Note nos. $\mathrm{H}_{23}$, $\mathrm{H}_{23} \mathrm{~K}$ ) were observed taking a total of $\mathrm{I} 4$ prey into their nests during a 3-hour period. One wasp $\left(\mathrm{H}_{23}\right)$ spent from 5 to 30 (mean 12.5 ) minutes between provisions; the other $\left(\mathrm{H}_{23} \mathrm{~K}\right)$ took longer ( $12-40$ minutes; mean 23). In every case the beetle was carried in flight, dorsal-side-upward and head-forward. The female grasped the beetle's antennae with the mandibles, and held its body with the legs. During one entry in which the entrance had been somewhat disturbed, the provisioning wasp, upon landing, was attacked twice by a female satellite-fly of the genus Senotainia (Sarcophagidae: Miltogramminae). She did not release the prey but entered in the usual manner.

Because of the concealed situation of the nest entrances, which were often behind overhanging plants and rootlets, the females were prevented from entering directly. One female $\left(\mathrm{H}_{23} 3\right)$ invariably landed outside on the cliff-face before diving in, and the other $\left(\mathrm{H}_{23} \mathrm{~K}\right)$, whose entrance was even more concealed (see Fig. 2), always landed on a plant to the left of the entrance and ran downward for a few centimeters before entering. The first wasp remained inside her nest, on the average, $11 / 2$ minutes before exiting to search for the next prey; the second wasp usually stayed inside $1 \frac{1}{2-2}$ minutes before appearing in the entrance. These relatively long periods of time were undoubtedly related to the considerable distances inside the nests to which the females had to proceed with the prey. The first female, apparently disturbed by our observations, made a 5-second orientation flight after taking the first prey inside, followed by a I-2-second orientation flight after the second prey, but thereafter she did not orient. The second female, also seemingly disturbed by our presence, made a I-2-second orientation flight after the initial prey was taken in but did not orient thereafter.

Cazier and Mortenson (1965) were unable to obtain information on the manner of prey transport of the female of $B$. distinctus they observed in Arizona. They described one activity which may have been the female's orientation flight. The wasp they observed was much more active than the ones we studied, spending from only 35 seconds to 6 minutes in the field between prey. After entering 
the nest, this female stayed inside $30-180$ seconds before exiting to search for additional prey. Although not specifically stated, her provisioning activities clearly increased in intensity from late morning to late afternoon.

Nest structure and dimensions. We excavated two nests of $B$. distinctus at the Colonie, N. Y., site and one of us (HEE) dug a nest of this species at Bedford, Mass. The two nests at Colonie were rather complicated in configuration, containing a number of branching and curving side burrows leading from a main tunnel. Because of the complexity of these nests, including much variation in the position and distance of the rearing cells from the entrance, we suspect that the wasps were utilizing, in part, the abandoned burrows of solitary bees and constructing short side burrows and cells therefrom. One nest $\left(\mathrm{H}_{23}\right)$, still being provisioned when excavated, contained 7 cells at distances of from 32 to $45 \mathrm{~cm}$ from the entrance (Fig. 4). The cells were built in at least two distinct clusters, cells $\mathrm{A}$ and $\mathrm{B}$ in one cluster containing larvae, and cells $\mathrm{C}-\mathrm{F}$ in another with eggs, plus an additional isolated cell $(\mathrm{G})$. Only 2-6 cm separated the cells within a cluster, and the closest cells in different clusters were $7-15 \mathrm{~cm}$ apart. The cells belonging to a cluster were oriented in one general direction and could have been made at the ends of short, branching side burrows leading from a single tunnel. None of the side burrows could be traced as they were filled with damp sand. A short main tunnel and three proximal side burrows which ended blindly were open and could be followed. The female was found in one of the side burrows, evidently extending this burrow in a different direction after having sealed off the last cell. She had been inside the nest for I I minutes after entering with the last prey and before we began our excavation.

The second nest at Colonie $\left(\mathrm{H}_{23} \mathrm{~K}\right)$, although more complex in structure than the first, was more compact, i. e., the cells were closer together and nearer the entrance (Figs. 3a, b). This nest contained a total of 8 cells and, likewise, was still being provisioned when excavated. Although the cells were oriented in different directions from one another, they appeared to be constructed in three distinct clusters containing two different stages of wasps. Cell A, holding a cocoon, was separated only $9 \mathrm{~cm}$ from the entrance. Cells $\mathrm{B}-\mathrm{F}$, also containing cocoons, were situated only $\mathrm{I}-7 \mathrm{~cm}$ apart at distances of from $\mathrm{I} 6$ to $22 \mathrm{~cm}$ from the entrance. The two most recent cells $(G, H)$, containing larvae, were unearthed 9-IO cm from the entrance on the other side of the burrow from cell $A$. As 


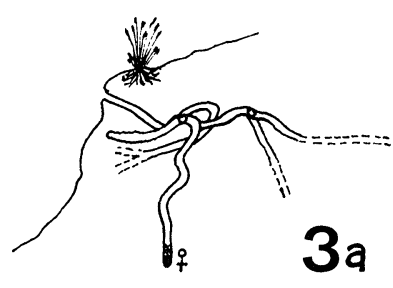

$10 \mathrm{~cm}$

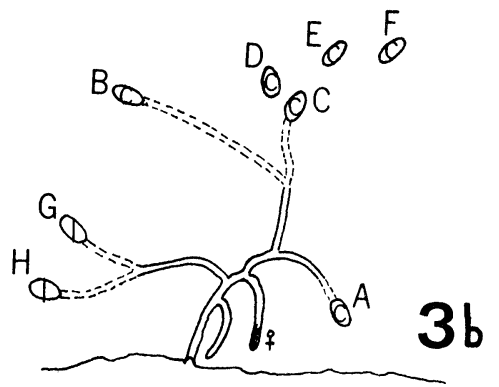

$$
C^{\otimes} \quad D^{\oplus} E^{\otimes} Q_{F}
$$
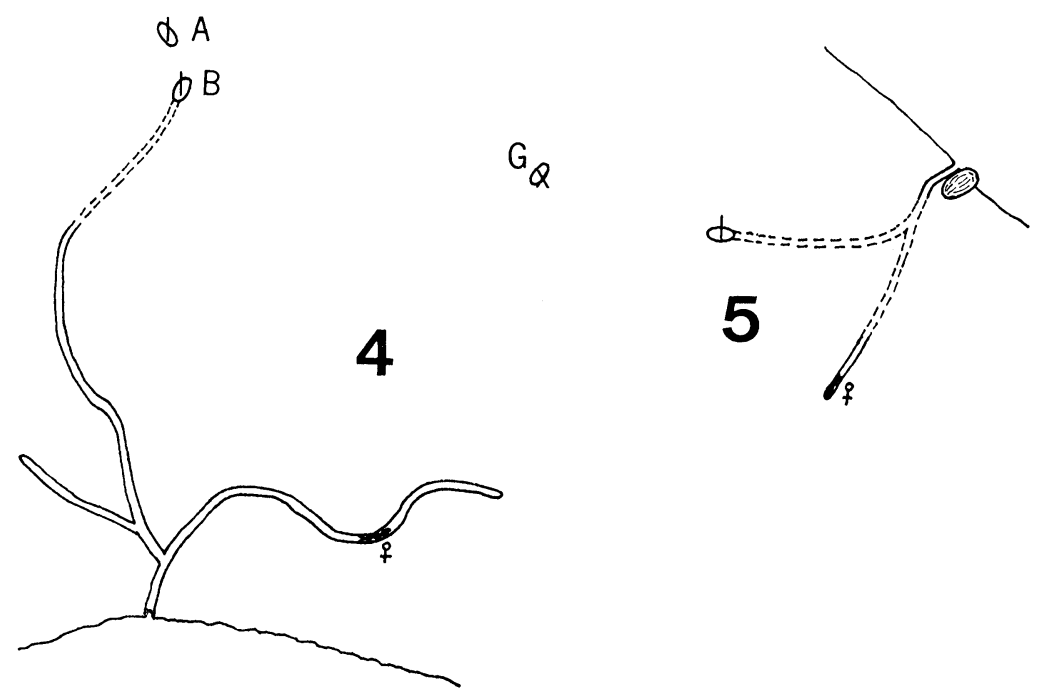

Figs. 3a, b. Side and top views of nest no. H23K (Colonie, N. Y.; 16 July 1970). Fig. 4. Top view of nest no. H23 (same locality; 7 July 1970). Fig. 5. Side view of nest no. 2306 (Bedford, Mass.; 23 Sept. 1971). Traceable burrows are indicated by solid lines, untraceable ones by dotted lines. Cells in Figs. 3b, 4 are lettered in apparent chronological order, according to contents. Cell contents are as follows: e, egg; l, larva; c, cocoon; $x$, contents destroyed. + shown where captured in burrow. Scale below Fig. 3a refers to all figs. 
in the first nest $\left(\mathrm{H}_{23}\right)$, the cells in this nest appeared to be built not in series but from short, branching side burrows leading from a single tunnel.

The nest at Bedford, Mass. (no. 2306), was evidently in an early stage of development when excavated. The entrance, $4 \mathrm{~mm}$ in diameter, led to several subterranean cavities of which one contained a cicindelid larva. Upon further digging, a single cell containing prey and a 3-mm-long larva was unearthed at a distance of $15 \mathrm{~cm}$ from the entrance (Fig. 5). The female was captured in another branch of the nest, $15 \mathrm{~cm}$ from the entrance.

At Colonie, the depths of the seven cells in the first nest $\left(\mathrm{H}_{23}\right)$ ranged from 22 to 44 (mean 32 ) $\mathrm{cm}$ beneath the surface, whereas those of the eight cells in the second nest $\left(\mathrm{H}_{23} \mathrm{~K}\right)$ ranged from $2 \mathrm{I}$ to 24 (mean 22.5) $\mathrm{cm}$. The relative uniformity in the latter set of figures is related to the fact that the nest was compact and the cells were constructed close to the edge of the mound, whereas in the first nest the cells were distributed from the edge of the mound to the top. There was no correlation between the depth of the cell or its distance from the entrance and the stage of the developing wasp. For example, in nest $\mathrm{H}_{23}$ the shallower cells nearer the entrance contained larvae and the deeper cells farther from the entrance held eggs. In nest $\mathrm{H}_{23} \mathrm{~K}$, on the other hand, the shallower cells nearer the entrance contained small larvae but the deeper cells farther from the entrance, mature larvae inside cocoons. The ovoidal cells were oriented either horizontally or sloped upward or downward in the soil at a $15-25^{\circ}$ angle. Five such cells at Colonie averaged $6(4-8) \times$ I I (IO-I2) $\mathrm{mm}$. One cell at Bedford was 5-mm-wide.

One of the females $\left(\mathrm{H}_{23} \mathrm{~K}\right)$ had been observed taking in prey nine days before we excavated her nest, indicating that she took an average of more than one day to complete a single cell. This may have been due to poor weather conditions. However, even during optimal weather conditions, our data on the provisioning times suggest that a female constructs and completes not more than two cells per day. Such a wasp probably remains with the same nest for several weeks, enlarging it and continuously adding new cells. Thus, a female of $B$. distinctus might renovate and use only one or a few nests during her lifetime in the northeastern United States. Cazier and Mortenson (1965) noted that the female they observed in Arizona interrupted her rather continuous provisioning activities a total of four times in one day and spent exceedingly long periods each time inside the burrow, probably in ovipositing and filling the burrow 
leading to the old cell and in constructing a side burrow and new cell. If such is the case, this wasp completed four cells in a single day and probably would not have remained with a nest for more than several days under optimal weather conditions.

Provisions. Females of $B$. distinctus preyed exclusively upon adult beetles of the family Chrysomelidae, subfamily Galerucinae. At Colonie, prey taken from cells of the first nest $\left(\mathrm{H}_{23}\right)$ included 29 specimens of Pyrrhalta decora (Say) and 3 of P. perplexa Fall. Both species occur on willow. Several cells in this nest contained only $P$. decora. Prey of the second nest $\left(\mathrm{H}_{23} \mathrm{~K}\right)$ comprised 4 P. spiraeae Fall (host: Spiraea), I P. perplexa, and I P. cavicollis (Leconte) (host: Prunus). The four prey collected from the nest at Bedford proved to be Ophraella notata (Fabr.) (host: Eupatorium perfoliatum). Cazier and Mortenson (1965) captured a female of $B$. distinctus in Arizona with her prey, Monoxia sp. (Chrysomelidae: Galerucinae). Except for those beetles which had been devoured by the wasp larvae, prey collected from all three nests at both Colonie and Bedford were alive as indicated by the movements of the legs and abdominal segments.

Fully-provisioned cells of $B$. distinctus contained from 4 to 9 beetles. Seven cells in nest $\mathrm{H}_{23}$ held 4-9 (mean 5) beetles per cell, and eight cells in nest $\mathrm{H}_{23} \mathrm{~K}$ contained $4-6$ (mean 5) prey per cell. The single cell excavated at Bedford had 4 beetles. The prey individuals weighed from 7 to 16 (mean II.4) and from 12 to I5 (mean $\mathrm{r} 3.6$ ) $\mathrm{mg}$, respectively, in nests $\mathrm{H}_{23}$ and $\mathrm{H}_{23} \mathrm{~K}$ (32, 7 beetles). A number of beetles from the second nest were damaged during excavation and were not weighed. The two wasps associated with these nests each weighed $10 \mathrm{mg}$, or slightly less than an averagesized beetle. The total weight of prey per cell in these nests ranged from 44 to 68 (mean 55.8) $\mathrm{mg}$ in four of the cells.

The beetles were placed in the cells in a variety of positions. In cells with few prey (4 or 5/cell), the individuals were mostly headinward but either dorsal-side-up, ventral-side-up, or on the side. Some beetles were even placed perpendicular to the long axis of the cell. The fact that most individuals were head-inward is linked to the manner of the female's transport of the beetle, i. e., head-forward.

$E g g$. The female of $B$. distinctus did not lay her egg until the full complement of prey had been put in the cell. In most cells the egg-bearing beetle was one of the innermost prey and was positioned ventral-side-upward and head-inward. In one nest $\left(\mathrm{H}_{23}\right)$, four such beetles weighed II-16 (mean 13.3) mg, or were slightly larger than the average-sized prey. 


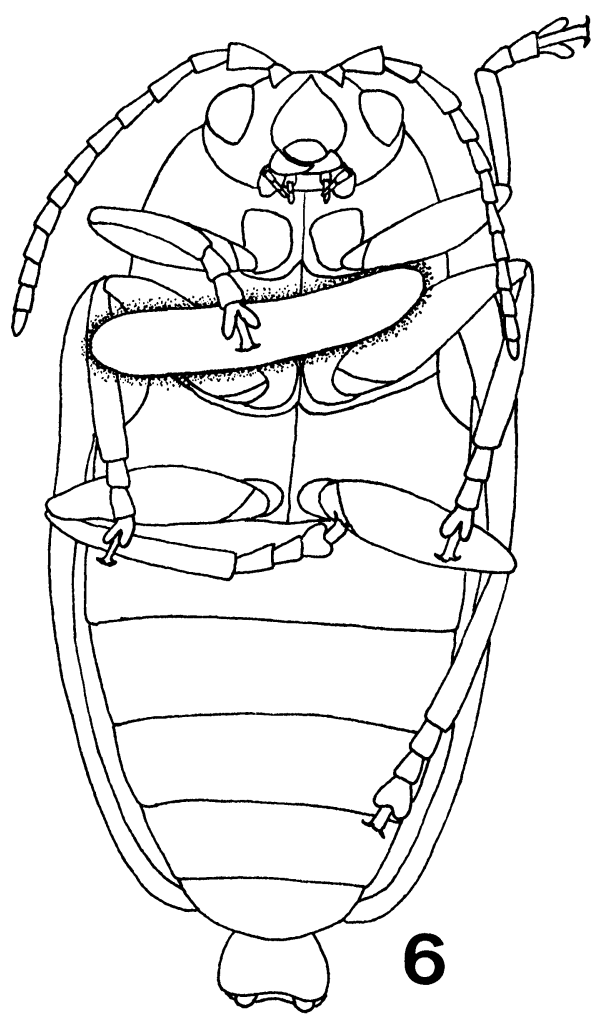

Fig. 6. Egg of Bothynostethus distinctus attached in typical position between pro- and midlegs of Pyrrhalta sp.

The whitish, elongate, curved egg, I.5 $\times 0.4 \mathrm{~mm}$, was attached by its cephalic end to the ventro-lateral portion of the thorax between a fore- and midleg (Fig. 6). The exact sternite, suture, or membrane to which it was attached could not be discerned. Although the caudal end of the egg extended slightly obliquely backward and was raised free above the opposite midleg, the position of the egg with respect to the long axis of the beetle's body was almost transverse. Eggs were attached to the left or right sides of the prey in about equal numbers. The larva began feeding at the site of the egg attachment. One larva, 2-mm-long, was noted feeding between the beetle's foreand midcoxa, and another, 3-mm-long, was attached near the juncture of the pro- and mesosternum. 


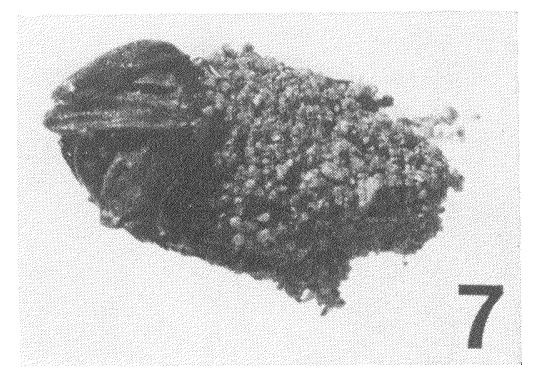

Fig. 7. Cocoon of Bothynostethus distinctus with beetle elytra attached to proximal end. (Photo by D. J. Peckham).

Cocoon. The cocoon of this species is oval-elongate in shape and dark brown in color. The walls consist of silk and possibly other oral secretions, with various-sized sand grains embedded externally (Fig. 7). Several beetle elytra were attached to the proximal end, i. e., the end nearest the entrance to the cell. The cocoon in Fig. 7 measured $9.5 \mathrm{~mm}$ long.

\section{Description of the Mature Larva}

Our description of the mature larva of Bothynostethus distinctus is based on two specimens taken from freshly made cocoons. These larvae had not yet passed their meconia, and, aside from the more compact body shape, they showed no obvious wear or other structural modifications.

Body (Fig. 9). Length $7.5 \mathrm{~mm}$; maximum width $2.8 \mathrm{~mm}$. Robust, slightly curved; pleural lobes very prominent, especially on thorax; prothorax with a pair of additional finger-like lobes that extend forward laterad of head; apical abdominal segment rounded, anus distinctly ventral and pre-apical. Spiracles (Fig. I5) small, lightly pigmented; atrial walls lined with weak, irregular polygons, opening into subatrium simple, unarmed. Integument densely spinulose on thoracic venter, but dorsum barely so; thoracic segments each with a transverse dorsal row of IO to 12 setae (up to $30 \mu$ long); pleural lobes and accessory prothoracic lobes smooth, but each terminating in 2 or 3 short setae.

Head (Fig. 8). Width $.86 \mathrm{~mm}$; height, excluding labrum, .80 $\mathrm{mm}$; largely unpigmented except mandibles; front longitudinally depressed just mesad of each antennal orbit; coronal suture and parietal bands barely evident. Antennal orbits of moderate size, 

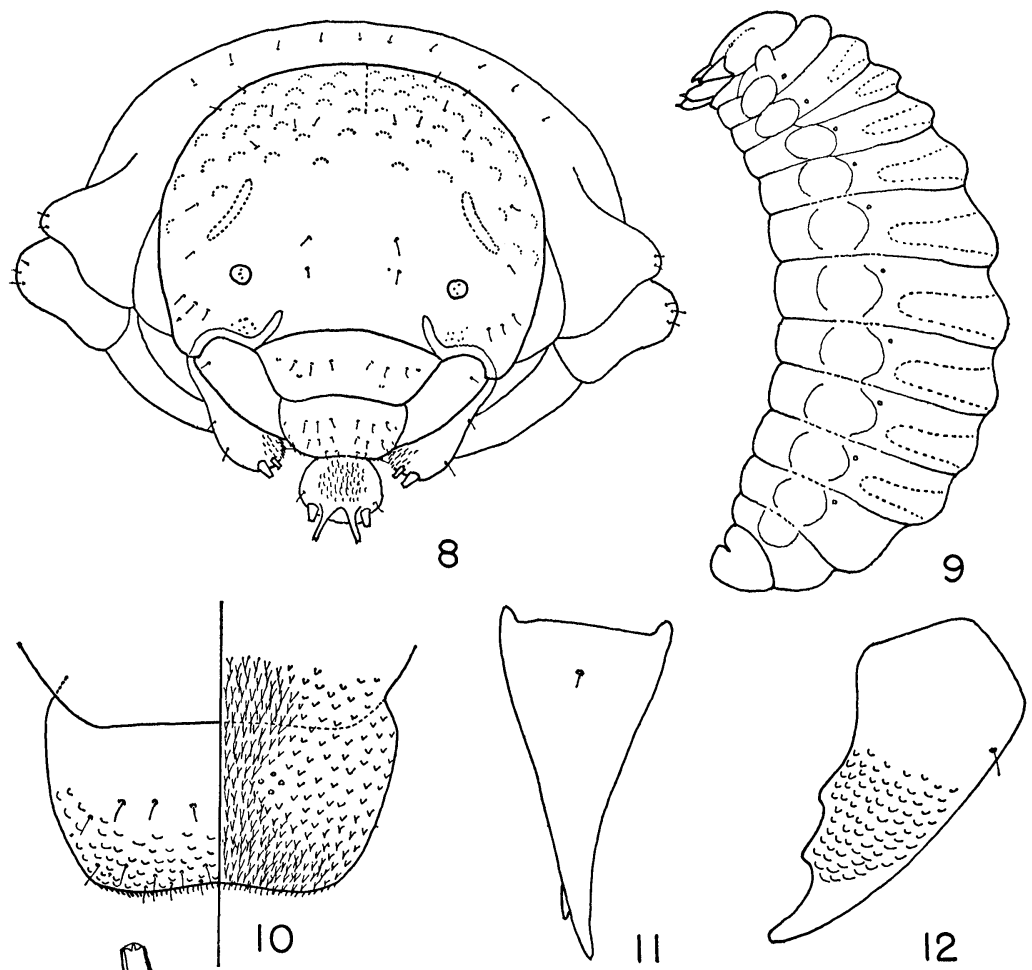

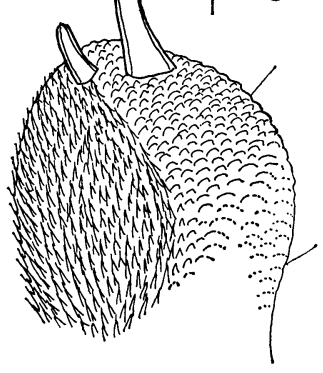

13

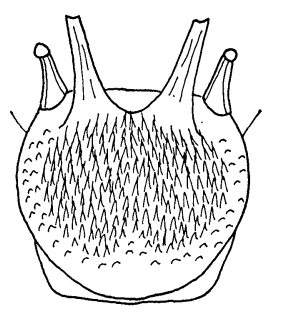

14

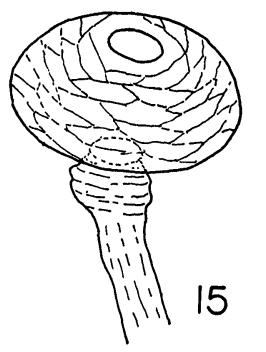

Figs. 8-15. Mature larva of Bothynostethus distinctus Fox. 8. Head in frontal view. 9. Body in side view. 10. Labrum (left) and epipharynx (right). 11. Mandible in side view. 12. Mandible in dorsal view. 13. Dorsal view of maxilla. 14. Dorsal view of prementum of labium. 15. Thoracic spiracle. 
each bearing three minute sensilla. Head setae sparse and short, the longest $40 \mu$; clypeus with few setae.

Mouthparts. Labrum (Fig. IO) truncate apically, bearing 8 setae across disc and 16 across apical margin, the margin with some minute, inconspicuous sensilla and rather weakly bristly; epipharynx strongly spinulose medially, with smaller and sparser spinules laterally; epipharyngeal sensory areas each with four sensilla. Mandibles (Figs. II, I2) slightly more than twice as long as their basal width, with three teeth on inner margin in nearly same plane; base with a single seta; upper surface roughened in area of teeth. Maxilla (Fig. 13) protruding, rounded, without an evident lobe on inner margin, densely spinulose along mesal margin; palpus about $80 \mu$ long, galea more slender, slightly more than half as long as palpus. Hypopharynx very densely spinulose. Labium (Fig. I4) with prementum densely and extensively spinulose; palpi about $60 \mu$ long, slightly curved, much exceeded by spinnerets.

Comments on larval characters. In the artificial key to genera of Sphecidae presented by Evans (1959, p. I6I), the larva of Bothynostethus runs to Entomognathus, a genus reconsidered in the paper that follows (Miller and Kurczewski, 1972). In the table of subfamily characters (ibid, p. I68) it runs to the couplet separating the Larrinae and Crabroninae, agreeing with the Crabroninae except in having accessory finger-like lobes on the prothorax as in many Larrinae. Distinctly crabronine features of Bothynostethus larvae are as follows: spiracular atrium weakly sculptured and opening into subatrium unarmed; mandibles slender and with teeth in about the same plane; mesal margin of maxilla not lobed. Very similar 3-toothed mandibles occur in Lindenius pygmaeus (Rossi) (Grandi, I928) and similar but 4-toothed mandibles are found in L. tylotis Court and R. Bohart and in other crabronine genera such as Crossocerus and Entomognathus (Evans, 1959). In most Crabroninae the spinules on the labium occur in two separate patches, but Bothynostethus is like Entomognathus in having the entire oral surface clothed with spinules. In several other features the larvae of these two genera are very similar: body setae and spinules are similar in size and distribution; the labrum is similarly shaped and with a similar distribution of setae and spinules; the form of the palpi, galeae, and spinnerets is virtually the same; and the spinules on the hypopharynx, maxillae, and labium are similarly dense and abundant. Entomognathus has no lobes on the prothorax, more head setae, and, as mentioned above, four-toothed mandibles. [This com- 
parison is based on Grandi's ( 1927 ) description of the larva of $E$. brevis Lind, and on Miller and Kurczewski's (1972) description of the larva of E. memorialis Banks].

\section{Discussion}

Considering the resemblances between the larvae of Bothynostethus and Entomognathus and the proposition that the Larrinae and Crabroninae may not deserve status as separate subfamilies (Evans, 1964), it seems worthwhile to compare the ecologies, nesting behaviors, and cocoon morphologies of members of these two littleknown genera. Such a comparison is now possible because Miller and Kurczewski have recently studied the behavior of Entomognathus memorialis Banks in some detail and have reviewed the literature on members of this genus in the following article.

Bothynostethus distinctus resembles Entomognathus memorialis and $E$. brevis Lind. in nesting in sand-cliffs and slopes, although the last species also nests in flat sand (Chambers, 1949). These three species plus E. texana Cresson possibly utilize pre-existing burrows for the proximal portions of their nests (Adlerz, 1912 ; Cazier and Mortenson, 1965); however, at least E. memorialis, in addition, constructs nests from the sand surface. In either case, searching for nest-sites involves characteristic hovering flights interspersed with soil sampling or hole searching, a behavior prevalent in Mimesa and Trypoxylon.

Although members of both genera transport the prey in flight in a head-forward position $E$. memorialis carries the beetle venter-up with the legs as in most crabronines (Pedal Type I, Evans, I962), whereas $B$. distinctus carries the beetle dorsum-up and, in addition to using the legs, grasps the prey's antennae with the mandibles as in many larrines (Mandibular Type 3). At least one species of Entomognathus, memorialis, stores prey in the burrow prior to their arrangement in the cell and oviposition. $B$. distinctus apparently takes the beetles directly into the cell. Many cells in the nests of $E$. memorialis are constructed in tandem series, whereas cells in the nests of $B$. distinctus are evidently built singly at the ends of short side burrows.

The use of a common family of beetles by members of these two genera should not be overemphasized, as many examples of convergence in prey type are known in the Sphecidae. One noteworthy example is the frequent use of the tarnished plant bug, Lygus lineolaris (Beauvois) by the larrine Plenoculus davisi Fox and by the crabronine Anacrabro ocellatus Packard (Kurczewski, 1968; Kurczewski and Peckham, 1970). It is entirely possible that 
the use of chrysomelids by Bothynostethus and Entomognathus was acquired independently and, furthermore, that the similarity in the position of egg attachment of these two genera was dictated by the morphology of the beetle [Compare Fig. 6 with fig. II in Grandi (1927) (E. brevis) and with Fig. 3 in Miller and Kurczewski (E. memorialis)].

The cocoons of species of Larrinae and Crabroninae are basically similar in shape and in having an outer covering of sand grains. That of Bothynostethus contains beetle elytra affixed to the proximal end and thus resembles cocoons of certain species of the crabronine genera Lindenius and Crabro, in which prey remains cover the outside. On the other hand, in larrine genera such as Lyroda, Plenoculus, and Tachysphex prey remains are not attached to the exterior of the cocoon and, in this respect, Entomognathus is much like a larrine [see Miller and Kurczewski, Fig. 4 (E. memorialis); Benoist, I9I5 (E. brevis)]. The reliability of the exterior structure of the cocoon as an indicator of phylogeny can, however, be questioned. For example, Oxybelus, a genus of the tribe Oxybelini which is usually placed in the Crabroninae, has a cocoon that is essentially indistinguishable from that of many Larrinae.

Thus evidence on the relationship of Bothynostethus and Entomognathus based upon cocoon structure is equivocal, and that derived for certain behavioral components is difficult to interpret. Although larval structure suggests that the two genera are closely related, Bothynostethus does possess finger-like lobes on the prothorax, an important larrine feature. In spite of some similarities among these two genera in adult external morphology, Bothynostethus and Entomognathus for the most part retain their affinities with other Larrinae and Craboninae, respectively. Both Krombein (195I) and Menke ( I968) concluded that Bothynostethus belongs in the Larrinae, while Entomognathus has consistently been placed in the Crabroninae.

Despite considerable similarity in larval morphology and several common ecological and behavioral features, we believe the two genera are sufficiently different to warrant their being placed in separate tribes. Therefore, we accept Menke's (1968) placement of Bothynostethus in the Bothynostethini, and support the retention of Entomognathus in the Crabronini. However, the resemblances among the larvae and cocoons of these and related genera lead one to ask again whether the larrine and crabronine wasps should not simply be considered as tribes within a single subfamily, as sug- 
gested by Evans (1964). Our study of Bothynostethus distinctus indicates that this matter should be left open until additional data can be obtained and further evidence weighed.

\section{ACKNOWLEDGMENTS}

We are grateful to J. A. Wilcox, New York State Museum and Science Service, for identifying the prey beetles. We are indebted to R. C. Miller, SUNY College of Forestry, for allowing us to examine his unpublished description of the larva of Entomognathus memorialis. D. J. Peckham, Upstate Medical Center, photographed the cocoon of $B$. distinctus. Funds, in part, for the senior author were provided by a Grant-in-Aid from the Research Foundation of the State University of New York (No. IO-7 I 6-A). The junior author was in residence at the E. N. Huyck Preserve, Rensselaerville, N. Y., when most of these observations were made.

\section{REFERENCES}

AdLerz, G.

1912. Lefnadsförhållanden och instinkter inom familjerna Pompilidae och Sphegidae. IV. K. Svenska Vet. Ak. Handl. 47: 1-61.

Benoist, R.

1915. Sur l'Entomognathus brevis Lind. (Sphegidae), Hyménoptère chasseur d'Altises. Bull. Soc. Ent. Fr. 20: 241-242.

Cazier, M. A. and M. A. Mortenson.

1965. Studies on the bionomics of sphecoid wasps. V. Bothynostethus distinctus and Entomognathus texana (Hymenoptera: Sphecidae). Pan-Pacif. Ent. 41: 30-33.

Chambers, V. H.

1949. The Hymenoptera Aculeata of Bedfordshire. Trans. Soc. Brit. Ent. 9: 197-252.

Evins, H. E.

1959. Studies on the larvae of digger wasps (Hymenoptera, Sphecidae). Part V: Conclusion. Trans. Amer. Ent. Soc. 85: 137-191.

1962. The evolution of prey-carrying mechanisms in wasps. Evolution 16: 468-483.

1964. The classification and evolution of digger wasps as suggested by larval characters. (Hymenoptera: Sphecoidea). Ent. News $75: 225-237$.

GRANDI, G.

1927. Contributi alla conoscenza degli Immenotteri melliferi e predatori. II. Documenti etologicie morfologici sul Crabro (Entomognathus) brevis v. d. Lind. Crabronide predatore di Alticidi. Redia 16: 69-78.

1928. Contributi alla conoscenza biologica e morfologica degli Immenotteri melliferi e predatori. VI \& VII. Boll. Lab. Ent. Bologna 1: 1-31, 259-324. 
HaNDLIRSCH, A.

1925. Geschichte, Literatur, Technik, Paläontologie, Phylogenie und Systematik der Insekten. In Schröder, C. Handbuch der Ento-

KoнL, F. F. mologie, Vol. 3, viii +1202 pp.

1896. Die Gattungen der Sphegiden. Ann. Naturhist. Hofmus. Wien 11: 233-516.

KROMBEIN, K. V.

1951. Tribe Miscophini. In Muesebeck, C. F. W., et al. Hymenoptera of America north of Mexico. Synoptic Catalog. USDA Agric. Monogr. 2: 940-945.

KURCZEWSKI, F. E.

1968. Nesting behavior of Plenoculus davisi (Hymenoptera: Sphecidae, Larrinae). J. Kansas Ent. Soc. 41: 179-207.

Kurczewski, F. E. And D. J. Peckham.

1970. Nesting behavior of Anacrabro ocellatus ocellatus (Hymenoptera: Sphecidae). Ann. Ent. Soc. Amer. 63 : 1419-1424.

MeNKE, A. S.

1968. New South American genera and species of the tribe Bothynostethini (Hymenoptera; Sphecidae; Larrinae). Acta Zool. Lilloana 22: 89-99.

Miller, R.C. ANd F. E. KURCZewsKr.

1972. A review of nesting behavior in the genus Entomognathus, with notes on E. memorialis Banks (Hymenoptera: Sphecidae). Pysche, 79: 61-78. 

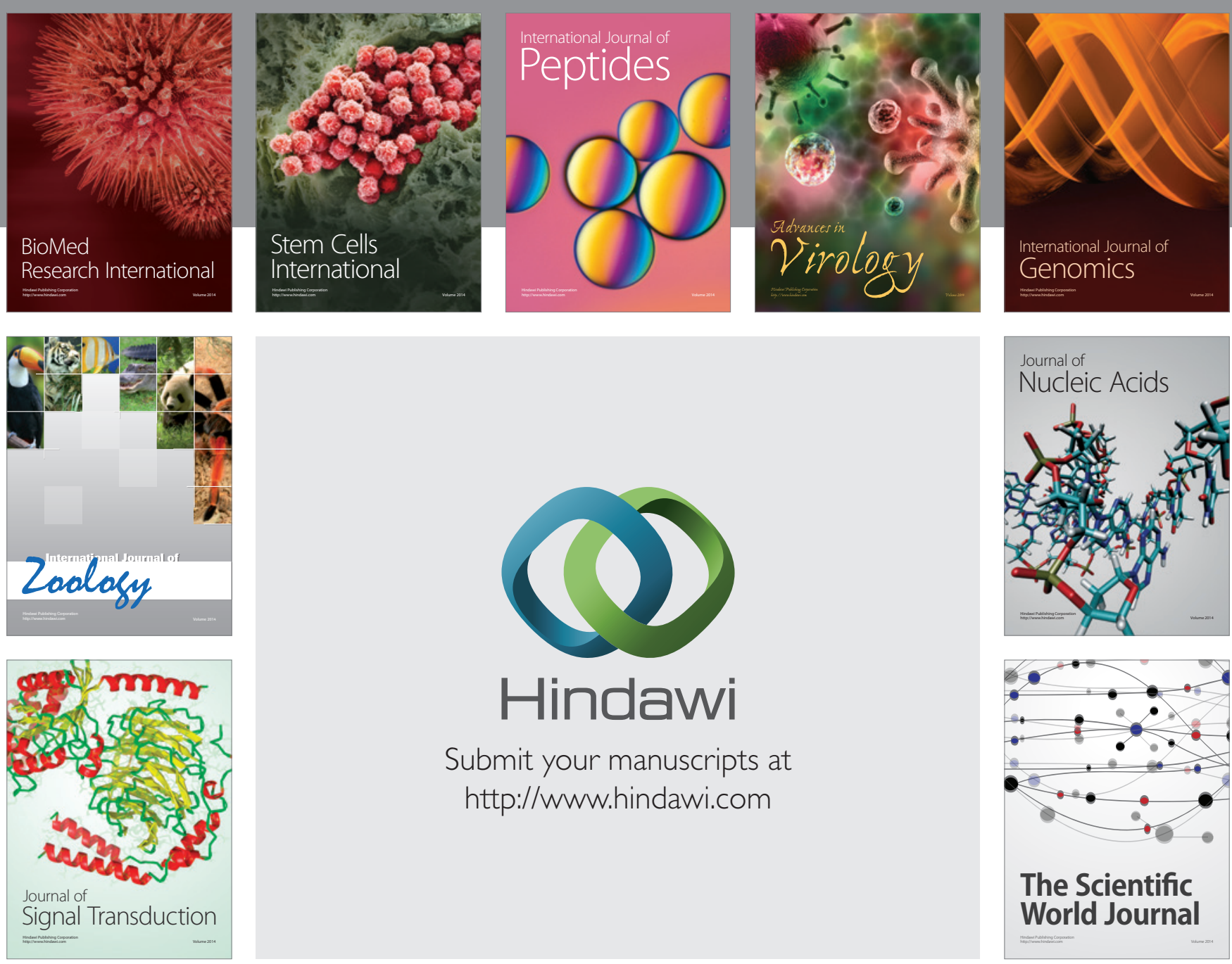

Submit your manuscripts at

http://www.hindawi.com
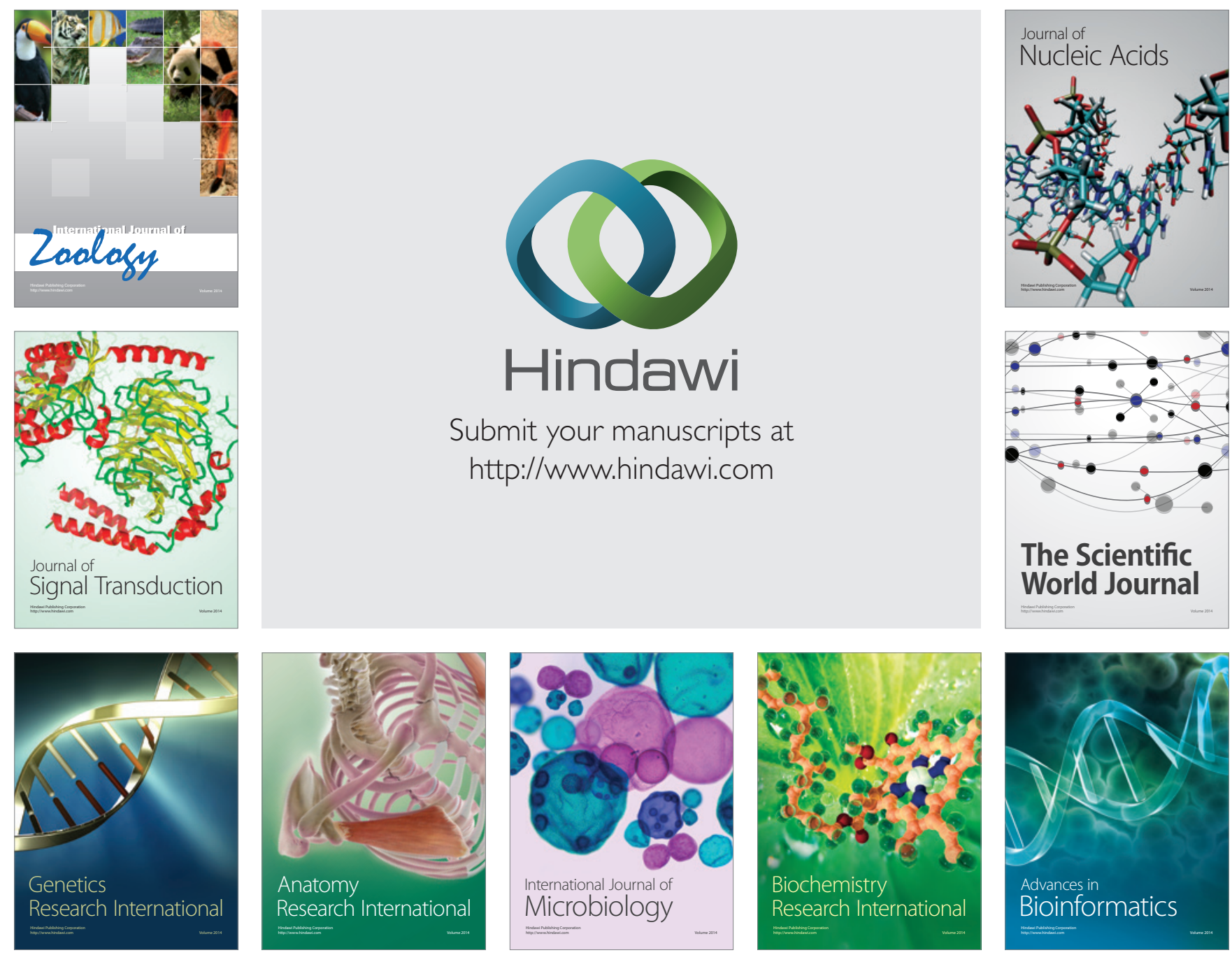

The Scientific World Journal
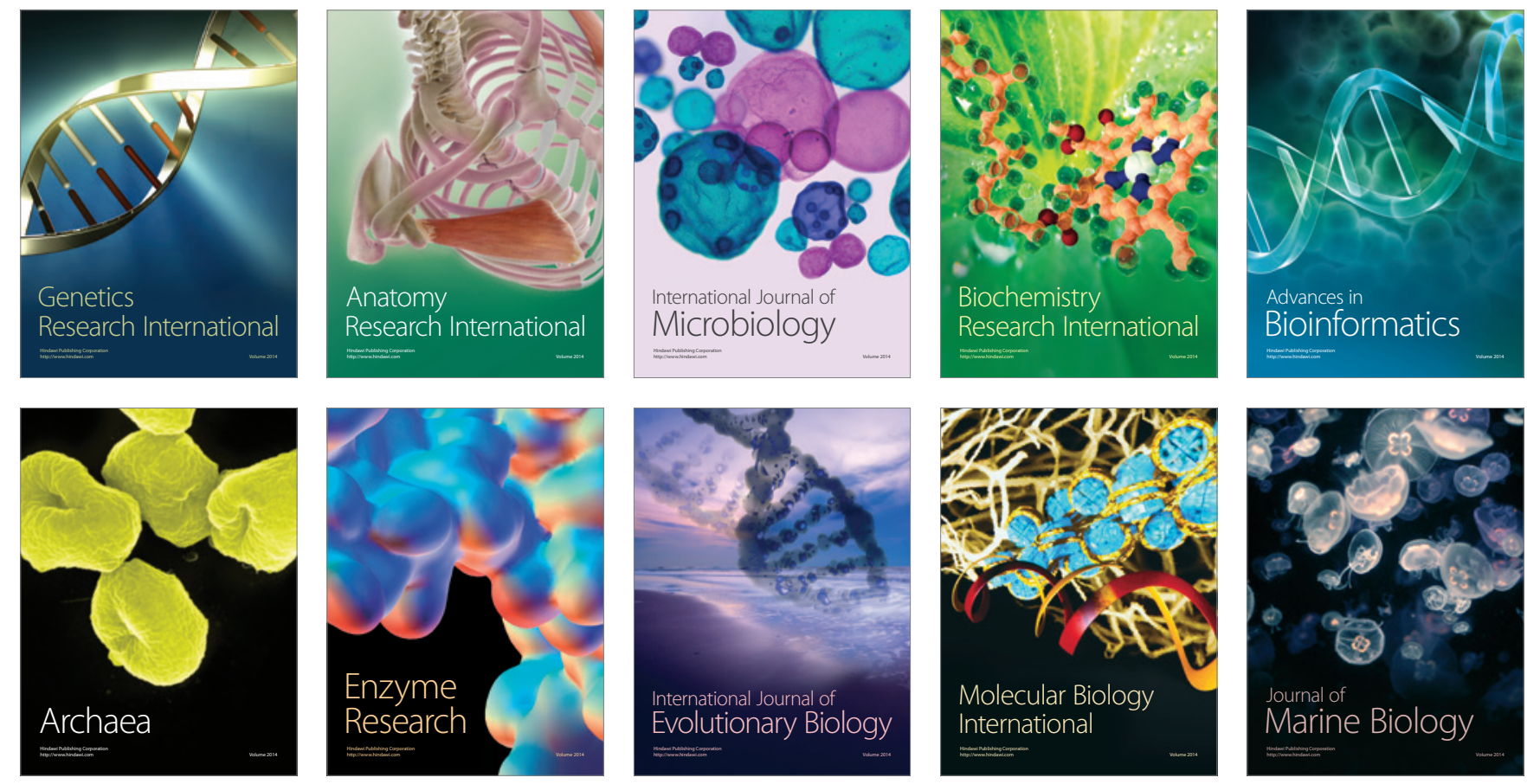